go to $11,000 \mathrm{ft}$. or even deeper if an oil-producing zone is not discovered at a shallower depth. One of the geological factors influencing the depth of this well is the great thickness of the recent deposits overlying very hard shale (Kreyenhagen). Operators believe in the possibility of very deep production at Kettleman Hills, and this is the first really serious attempt which has been made to test the lower formations in this region.

\section{Asparagus Growing}

The imposition of a tariff on certain imported fruits and vegetables has made it possible for English growers to produce certain crops which before were unprofitable. One of these is asparagus, and it is therefore particularly opportune that the Ministry of Agriculture has issued a Bulletin (No. 60, "Asparagus", 1s. net) which deals with its cultivation and marketing. A useful preliminary account traces the history of asparagus from Roman times and also outlines the botany of the plant. Varieties are described in fair detail and experiments on the use of unisexual plants are outlined. Male plants tend to give a large number of buds whilst female plants produce fewer but larger sticks. Methods of cultivation in Italy, France, Germany, the United States and England are given, and marketing is also discussed. The main pest of asparagus, the asparagus beetle, is described, as are also several fungus diseases. The canning industry is growing in England, and its needs have been borne in mind by the writer of the bulletin.

\section{Legal Medicine in the United States}

The resources of the various States of the Union for dealing with medico-legal problems in the administration of justice have been examined by a committee of the National Research Council, and the results of this survey are contained in a volume recently issued (Bull. Nat. Res. Council, No. 87, National Academy of Sciences, Washington, D.C., 1.50 dollars). It is pointed out that the determination of the cause of death, when a medico-legal question is involved, is the work of the skilled pathologist, who should be in a position to call to his aid the resources of bacteriologist, toxicologist, chemist, and others. Determination of mental responsibility is the work of the skilled psychiatrist. The detection of crime may at times require the application of pure and applied sciences in addition to the medical sciences. In the United States, there is as yet nothing comparable to the first-class medico-legal institutes of Europe.

\section{Relativity}

THE addresses and discussions at the conference on relativity in May 1930, which Prof. P. Langevin organised and presided over, have been published by Messrs. Hermann of Paris in the form of pamphlets of 14-30 pages at 6 or 7 franes in their series of Actualités Scientifiques et Industrielles. The principal titles are:- "Cinématique de la Relativité" by
M. E. Bauer of the Collège de France, "L'Inertie de L'Énergie" by M. F. Perrin of the Faculté, "Méchanique Ondulatoire" by Prof. L. de Broglie of the Sorbonne, "La Théorie Einsteinienne de la Gravitation" by Prof. G. Darmois of the University of Nancy, "La Théorie Unitaire du Champ" by Prof. E. Cartan of the Sorbonne and "La Relativite" by Prof. P. Langevin. In all cases the subject is presented in a very readable form and Prof. Langevin's address summing up the general results is especially interesting. He also contributes a simple proof of the Lorentz transformation to the discussion on the kinematics of the subject.

\section{Announcements}

THe Bakerian lecture of the Royal Society will be delivered on Thursday, May 25, at 4.30 p.m. by Dr. J. Chadwick, who will take as his subject "The Neutron",

ON account of alterations and repairs which are being made to Flamsteed House, the official residence of the Astronomer Royal, it will not be possible this year to hold the customary garden party at the Royal Observatory on the occasion of the annual visitation by the Board of Visitors on Saturday, June 3.

THE annual congress of the South-Eastern Union of Scientific Societies will be held at Norwich on June 7-10. The president-elect is Prof. E. J. Salisbury, Quain professor of botany in University College, London. The presidential address is entitled "The Influence of Man on Vegetation". The congress will be divided as usual into the following sections : geology, botany, archæology, zoology, and regional survey. Several interesting excursions have been arranged in connexion with the congress. The local secretary is Dr. H. A. Castigan, principal of the Technical College, St. George Street, Norwich.

THE fourth International Congress of Radiology will be held in Zurich, under the presidency of Prof. H. R. Schinz, professor of radiology in the University of Zurich, on July 24-31, 1934. Members of radiological societies in all countries, and other persons introduced by such societies, are eligible for membership. At the general meetings the following subjects will be considered, among others : radiation genetics ; mitogenetic radiation; structure analysis; identical physical measurement of the dose in X-ray and radium treatment; hard gamma-rays, cosmic radiation, earth radiation; and short-wave therapy. During the Congress, an exhibition of apparatus, photographic accessories, chemical products and scientific books will be on view. The general secretary of the Congress is Dr. H. E. Walther, Gloriastrasse 14, Zurich.

THE third International Congress of Linguistics will be held at Rome on September 19-26. The Congress will meet in three sections, of which the first will deal with general questions, the second with the Indo-European languages, and the third with the 